\title{
Environmental Monitoring of Soils of Post-Industrial Mining Areas
}

\author{
Volodymyr Pohrebennyk ${ }^{1}$, Piotr Koszelnik ${ }^{2 *}$, Olena Mitryasova ${ }^{3}$, \\ Elvira Dzhumelia', Monika Zdeb²
}

1 Lviv Polytechnic National University Stepana Bandery St, 12, L'viv, L'vivs'ka oblast, 79000, Ukraine

2 The Faculty of Civil and Environmental Engineering and Architecture, Rzeszow University of Technology, Powstancow Warszawy 12, 35-084 Rzeszow, Poland

3 Department of Ecology and Environmental Management of Medical Institute, Petro Mohyla Black Sea National University, 10, 68-Desantnykiv Steet, Mykolayiv oblast 54003, Ukraine

* Corresponding author's e-mail: pkoszel@prz.edu.pl

\begin{abstract}
The ecological situation in most mining regions of Ukraine is critical, and the closure of unprofitable mining enterprises, mines and cuts creates the environmental problems associated with significant changes in the geological and hydrological environment. The purpose of the work is the environmental monitoring of heavy metals in the soils in the territory of Rozdil State Mining and Chemical Enterprise (SMCE) "Sirka" at the stage of liquidation.The object of the study involves the heavy metals in soils in the territory of Rozdil SMCE "Sirka". The subject of the study is to evaluate the content of heavy metals and migration aspects in soils. In this work, the parameters of soil pollution with heavy metals were determined experimentally. On the example of Rozdil SMCE "Sirka", the main problems of the monitoring system of the territory of the mining and chemical enterprise at the stage of liquidation were proven. The influence of the mining and chemical enterprise on the state of environmental pollution (soil, water environment, and waste management status) was also assessed. The ecological balance of the territory is violated due to the fact that the elimination of negative technical manifestations of the enterprise activity was considered unprofitable for a long time. The development of monitoring techniques for man-made landscapes, along with the development of methods for diagnosing the specifics of their functioning and technologies for reclamation, is an integral part of multidisciplinary research on environmental imbalances, which is caused by the transformation of natural landscapes into man-made. The necessity of developing the information-analytical system for the monitoring of the Rozdil State Mining and Chemical Enterprise (SMCE) "Sirka" territory at the stage of liquidation was substantiated. It was established that the monitoring of the territory of the mining and chemical enterprise at the stage of liquidation will allow increasing the level of environmental safety of the territory of the enterprise and the surrounding settlements. Monitoring is one of the main stages of the liquidation and reclamation process and should be carried out at all stages of liquidation. In addition to the monitoring system in the process of liquidation and in the post-reclamation period, the liquidation project should include an environmental analysis of the enterprise activities and environmental forecasting.
\end{abstract}

Keywords: mining and chemical enterprise, environmental monitoring, heavy metals, reclamation, rehabilitation.

\section{INTRODUCTION}

Operation in the territory of the country of many high-risk objects, mainly in the zones with the high concentration of population, dramatically increases the danger of major man-made disasters, provokes and increases the negative impact of particularly dangerous natural phenomena. Each year, the losses from such emergencies are measured by thousands of human lives, billions of losses and irreparable damage to the natural environment.

The closure of a mining enterprise is the final and specific stage of its existence. It is inextricably linked with the stages of its construction and operation, and technologically largely determined by the mining technical conditions of the existing mining site. 
The closure of a mining enterprise is no less difficult than its construction and operation in terms of the number of tasks to be solved, multivariances, and the uncertainty of the conditions for making possible decisions and the unpredictability of their consequences.

The closure of mining enterprises requires solution of not only complex technical issues (elimination of trunks and other mining operations, objects of the surface complex) but also very responsible socioeconomic and environmental tasks designed to provide social protection of massively released workers, as well as technological and environmental long-term safety. The lack of an integrated approach to the problem of mine closure, poorly thought-out and unreasonable technological decisions, as practice shows, lead to the fact that some mining regions turn into the areas of social, economic and environmental disaster.

The accumulated industrial waste constitutes a significant problem after the closure of mining and chemical enterprises. Thus, soils, surface and underground water become polluted. The problem of unauthorized landfills of domestic and industrial waste deserves priority attention in $\mathrm{Eu}-$ rope. The costs of mitigating environmental pollution in Europe are over 10 billion euros.

Soil is a mixture of organic and mineral product of many years of joint activity of living organisms, water, air, solar heat and light. These natural formations are characterized by fertility; they provide plants with nutrients (potassium, carbon, nitrogen, phosphorus, etc.) and everything necessary for their livelihoods.

Soil contamination with heavy metals such as Arsenic, Mercury, Cadmium, Lead, Chromium, Copper, Zinc is quite dangerous.

According to the World Health Organization, Lead, Mercury and Cadmium are the most dangerous heavy metals. In recent years, high toxicity has been shown for Beryllium, Arsenic, Selenium, Antimony, Thallium, Nickel, Tin, and Vanadium, which are biologically active. The toxic chemical elements are divided into hygienic hazard classes according to the degree of threat in accordance with the state standards of Ukraine. By class they are:

Class I: Arsenic (As), Beryllium (Be), Mercury (Hg), Selenium (Sn), Cadmium (Cd), Lead $(\mathrm{Pb})$, Zinc ( $\mathrm{Zn})$, Fluorine $(\mathrm{F})$;

Class II: Chromium (Cr), Cobalt (Co), Boron (B), Molybdenum (Mo), Nickel (Ni), Copper $(\mathrm{Cu})$, Antimony $(\mathrm{Sb})$;
Class III: Barium (Ba), Vanadium (V), Tungsten (W), Manganese (Mn), Strontium (Sr).

In the first place, the content of heavy metals in the first class of danger is controlled, in the second - the content of heavy metals of the second grade of danger, in the third place - the third grade. Classification of soils by the degree of pollution of heavy metals is carried out for the MPC and the background content in the soil. By degree of contamination, the soil is divided into heavily polluted, medium-polluted, and slightly polluted (Bilous and Chopyk 2002, Kopach et al. 2009, Gajdyn et al. 1999, Rudko and Shkitsa 2002).

\section{PROBLEM STATEMENT}

The question of the methodology of environmental monitoring of disturbed lands is closely linked with the scientific and practical tasks related to the previously conducted observations of the state of the territory from the moment the land is extracted from the mining enterprise until the return to the previous owner or reverting to the previous state, which is unlikely, or until the creation of the respective landscapes.

Monitoring is one of the forms of implementation of processes of ecological activity with the help of means of information and supplies regular assessment and forecasting of the state of the environment of each person's life, the conditions of ecosystem functioning for making managerial decisions on environmental safety, preservation of the natural environment and rational nature management. The main tasks of such monitoring are:

- organization of a unified state control system for the components of the natural environment;

- the establishment of an automated system for the collection, processing, compilation and storage of information on the quantity and condition of the use of natural resources;

- inventory of the pollution sources, study on the degree of anthropogenic impact on the environment;

- modelling and forecasting the changes in the environmental situation and the state of the environment;

- development of managerial decisions aimed at ensuring rational nature management and sustainable development of the region.

Today, after the completion of minerals development, as a rule, there is a question of developing projects for the construction of disturbed 
territories. One of the important elements of such projects is environmental monitoring, which involves identifying and assessing the anthropognic processes and phenomena that can negatively affect the natural environment, lead to accidents and crises. In our opinion, this is a one-sided, only ecological approach, by which it is impossible to predict or predict the creation of appropriate landscapes in the disturbed territories. The evidence of this is that so far there is no ecological-landscape monitoring in Ukraine, which involves the formation of ecologically-man-made landscapes on disturbed lands, taking into account the former natural landscapes and the present, created by human production activities.

In order to reduce the harmful effects of heavy metals, appropriate rules for their content are introduced:

1. MPC of the gross content of heavy metals in the arable layer of soil and plant mass, $\mathrm{mg} / \mathrm{kg}$;

2. MPC of moving forms of heavy metals in soil, $\mathrm{mg} / \mathrm{kg}$;

3. Clarke of heavy metals in soil, $\mathrm{mg} / \mathrm{kg}$.

4. Pollution of soil by industrial facilities is a serious potential threat to the human health, ecosystems and the economy as a whole. The consequences are not yet clearly identified due to the presence of a large number of dangerous compounds and their various contents in the soil.

The consequences can be as follows:

- the reception of hazardous substances into the soil, surface and groundwater;

- the absorption of pollutants by plants;

- direct contact of people with the contaminated soil;

- inhalation of dust particles or volatile substances;

- fire or discharge of gases in landfills of domestic and industrial waste;

- corrosion of pipes and other elements of underground communications;

- formation of harmful secondary waste;

- conflicts during land cultivation and use (Poberezhna 2015).

\section{PURPOSE OF RESEARCH}

According to the State Register of Potentially Hazardous Objects (PHO) of Ukraine, Rozdil State Mining and Chemical Enterprise "Sirka" belongs to the monitoring facilities of PHO [6].
The purpose of the work is the environmental monitoring of heavy metals in soils in the territory of Rozdil State Mining and Chemical Enterprise (SMCE) "Sirka" at the stage of liquidation.

The object of the study involved the heavy metals in the soils in the territory of Rozdil SMCE "Sirka". The subject of the study was to evaluate the content of heavy metals and migration aspects in soils.

\section{SITE INFORMATION}

The research was carried out on the territory of Rozdil SMCE "Sirka". Rozdil State Mining and Chemical Enterprise "Sirka" is located in the West of Ukraine (Lviv region) of the Dniester River basin. The enterprise is located between latitudes $49^{\circ} 28^{\prime} 32.20^{\prime \prime} \mathrm{N}$ and $49^{\circ} 25^{\prime} 53.18 \mathrm{~N}$, and longitudes $24^{\circ} 6{ }^{\prime} 21.46^{\prime \prime} \mathrm{E}$ and $24^{\circ} 5^{\prime} 12.22^{\prime \prime} \mathrm{E}$ (Fig. 1). On the balance sheet of this enterprise, there are storage technological waters - artificial lakes Hlyboke, Serednie, Kysle, Chyste.

Due to the long-term activity (1956-1996) of Rozdil SMCE "Sirka" on its territory different wastes were formed. They are the sources of environmental hazard:

- lump sulphur - $700 \mathrm{~m}^{3}$;

- sulphur ore tailings - 85 million t;

- sediment of recycled waters -1.29 million $\mathrm{m}^{3}$;

- phosphogypsum - 3 million t;

- oil tars (imported from Hungary) - 17 thousand $\mathrm{t}$;

- solid household waste -560 thousand $\mathrm{m}^{3}$.

The main activity of Rozdil State Mining and Chemical Enterprise "Sirka" is the implementation of environmental works according to the project: "Liquidation of sulfur quarries and restoration of ecological balance and landscape around activity of Rozdil State Mining and Chemical Enterprise 'Sirka'".

\section{METHODS OF ANALYSIS}

The samples which were selected in 2016, were analyzed with the mass spectral technique. Mass spectrometry (MS) is an analytical technique that ionizes chemical species and sorts the ions based on their mass-to-charge ratio. In simpler terms, a mass spectrum measures the masses within a sample. Mass spectrometry is used in 


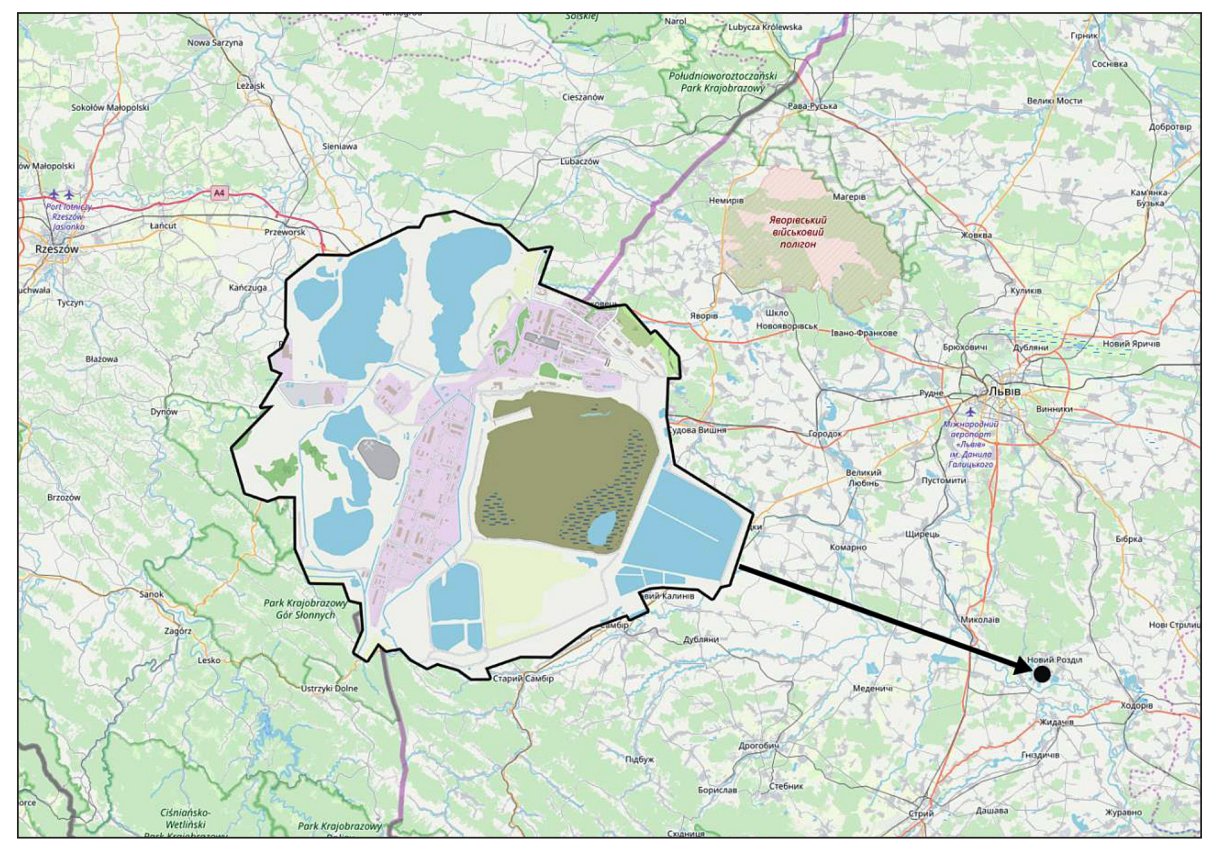

Fig. 1. Location of the study area. Source: OpenStreetMap

many different fields and is applied to pure samples as well as complex mixtures. A mass spectrum is a plot of the ion signal as a function of the mass-to-charge ratio. These spectra are used to determine the elemental or isotopic signature of a sample, the masses of particles and of molecules, and to elucidate the chemical structures of molecules and other chemical compounds.

It is based on the method of the stepwise weakening of spectral lines (Cler's method). The method of the stepwise weakening was employed because the intensity of the spectral lines, photographed in violation of the spectrum of one of the analyzed samples, decreases gradually in height with the help of the special weakener, found directly in front of the input gap of the spectrograph. Because of the visual consideration of spectral lines in the specimens photographed in this way by samples of standard samples, we can draw up tables or construct the dependences of the number of observed degrees for analytic lines of elements from their concentration in the sample.

Along with the traditional use in metallurgy and industrial enterprises for the analysis of metals and alloys, in geology, archeology, astrophysics, analytical chemistry, spectral analysis is increasingly often used in such fields as ecology, food industry, agriculture and medicine. The application of spectral analysis in ecology is an analysis of sewage sludge in preparation of the technology for their processing, bottom sediments, analysis of soils, water, plants, animal hair and human hair ashes for assessing the zone of environmental damage.

The sensitivity of this method is very high: with the help of spectral analysis, it is possible to detect an element in the substance, even if its mass does not exceed $0.1 \mathrm{ng}$ (Fetzer 2014).

Soil sampling, carried out in 2017, was analyzed using X-Ray Diffraction (XRD) technique. The concentration of elements in the sample was determined by X-ray spectrometry using an S2 PICOFOX Bruker X-ray spectrometer - detector type: silicon drift detector, high voltage generator: MNX 50P50/XCC, X-ray source: metal ceramic air cooled MCB50-0.7G, X-ray optics: multilayer monochromator.

Direct sample preparation.

1. An aqueous solution of a concentrated gallium standard $(100 \mu \mathrm{l})$ in distilled water $(10 \mathrm{ml})$ was prepared.

2. $1 \mathrm{ml}$ of the sample was added to $20 \mathrm{ml}$ of a gallium standard water solution and mixed well in vortex ( 5 seconds).

3. The prepared samples were applied to quartz media and analyzed on an X-ray spectrometer. The analysis time was 1000 seconds. The determinations were carried out in the manual off mode - work at maximum 50 W lamp power, $50 \mathrm{keV}$ energy.

4. The results are expressed in units of $\mu 1 / 1$ (Gauglitz and Moore 2014, Epp 2016). 


\section{RESULTS OF RESEARCH}

The main threats to be considered at the stage of the deposit the exploitation completion are chemical pollution of soils, waters, geophysical disturbance of the stability of the territory (Pohrebennyk et al. 2017). There is the satellite image of the territory of the enterprise and the main sources of ecological danger (Fig. 2).

Heavy metals are present in the soil as natural impurities, and the reasons for increasing their concentrations are related to human activity. There are the geographic coordinates of the sampling points (Table 1). The results of measurements were obtained by the following parameters: Strontium, Manganese, Zinc, Lead, and Arsenic.

Soil pollution is a result of economic activity in the past and present. Since the content of heavy metals within the limits of maximum permissible concentrations is important, the dynamics of changes in the content of heavy metals in soils is presented in Fig. 3-8. In 2016, the content of Manganese in soil in 2016 almost reached the MPC $(1500 \mathrm{mg} / \mathrm{kg})$ near the dump of phosphogypsum at a distance of $20 \mathrm{~m}$ and a depth of $0.2 \mathrm{~m}$.

The MPC of Strontium in soil is $1000 \mathrm{mg} / \mathrm{kg}$. On the territory of the enterprise, there are significant excess of MPC (up to 6 times). Over time, the content of Strontium in the soil does not decrease.
In 2016, Zinc was not detected in soil samples. The data for 2017 (for Zinc) are shown in Fig. 5, 6. MPC of Zinc is $300 \mathrm{mg} / \mathrm{kg}$. Excess was not detected. The rate of Zinc migration to the depth in the soil decreases in the polynomial dependence $y=-41.78 \ln (\mathrm{x})+102.75$, the magnitude of the probability of approximation is highest $R^{2}=0.9224$. For comparison with linear dependence $(y=-19.34 \mathrm{x}+117.9)$, the probability of approximation is $R^{2}=0.9114$, with exponential dependence $R^{2}=0.9054\left(\mathrm{y}=132.79 \mathrm{e}^{-0.28 x}\right)$.

Fig. 7-8 show the dynamics of changes in the content of Lead in soils. MPC of Lead is $30 \mathrm{mg} / \mathrm{kg}$. Excess was detected only in 2017 at a sampling point of $5 \mathrm{~m}$ from the dump of phosphogypsum at a depth of $0.40 \mathrm{~m}$. On the surface of the soil there is a tendency to decrease the content of Lead, depending on the distance from the dump of phosphogypsum.

In 2016, Arsenic was not detected in soil samples, but in 2017 it was (Fig. 9). MPC of Arsenic in soil is $2 \mathrm{mg} / \mathrm{kg}$. There are MPC excess at 4 sampling points. At the distance of $20 \mathrm{~m}$ from

The system of monitoring of the territory of the mining and chemical enterprise at the stage of liquidation will allow increasing the level of environmental safety of the enterprise territory and the surrounding settlements as well as enable to timely react to adverse changes.

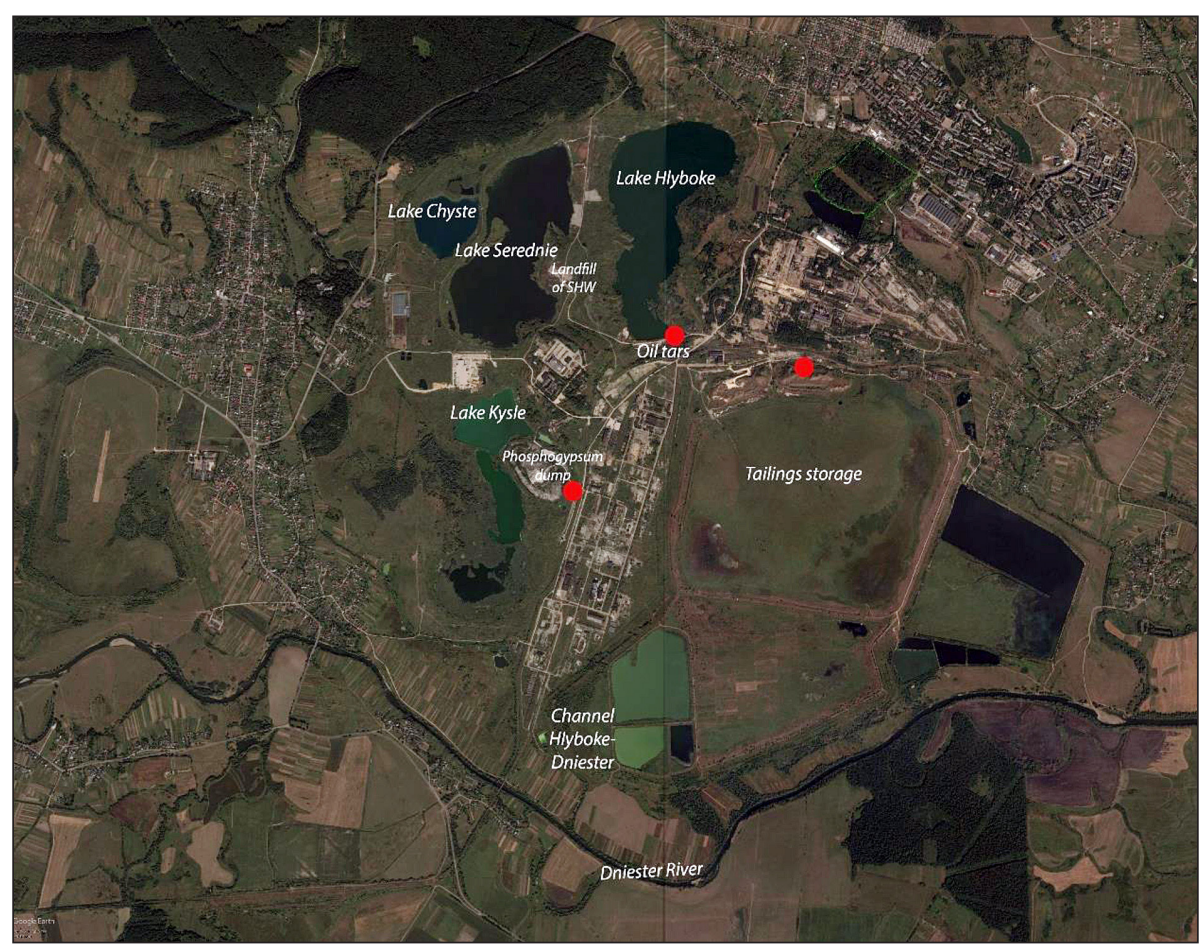

Fig. 2. Satellite image of Rozdil State Mining and Chemical Enterprise "Sirka" and sampling points. Source: Google Map 
Table 1. Geographic Coordinates of Sampling Points

\begin{tabular}{|l|c|c|}
\hline \multicolumn{1}{|c|}{ Place } & Latitude & Longitude \\
\hline $1 \mathrm{~m}$ from oil tars & $49^{\circ} 27^{\prime} 30.0 » \mathrm{~N}$ & $24^{\circ} 6^{\prime} 15.0 » \mathrm{E}$ \\
\hline $5 m$ from oil tars & $49^{\circ} 27^{\prime} 30.12 \mathrm{~N}$ & $24^{\circ} 6^{\prime} 14.98 » \mathrm{E}$ \\
\hline $10 m$ from oil tars & $49^{\circ} 27^{\prime} 30.28 » \mathrm{~N}$ & $24^{\circ} 6^{\prime} 14.96 » \mathrm{E}$ \\
\hline $20 m$ from tars & $49^{\circ} 27^{\prime} 30.60 » \mathrm{~N}$ & $24^{\circ} 6^{\prime} 14.91 » \mathrm{E}$ \\
\hline $\begin{array}{l}1 m \text { from } \\
\text { phosphogypsum }\end{array}$ & $49^{\circ} 26^{\prime} 55.94 » \mathrm{~N}$ & $24^{\circ} 5^{\prime} 42.98 » \mathrm{E}$ \\
\hline $\begin{array}{l}5 m \text { from } \\
\text { phosphogypsum }\end{array}$ & $49^{\circ} 26^{\prime} 55.89 » \mathrm{~N}$ & $24^{\circ} 5^{\prime} 43.16 » \mathrm{E}$ \\
\hline $\begin{array}{l}10 m \text { from } \\
\text { phosphogypsum }\end{array}$ & $49^{\circ} 26^{\prime} 55.83 » \mathrm{~N}$ & $24^{\circ} 5^{\prime} 43.39 » \mathrm{E}$ \\
\hline $\begin{array}{l}20 m \text { from } \\
\text { phosphogypsum }\end{array}$ & $49^{\circ} 26^{\prime} 55.71 » \mathrm{~N}$ & $24^{\circ} 5^{\prime} 43.86 » \mathrm{E}$ \\
\hline $1 \mathrm{~m}$ from sulfur & $49^{\circ} 27^{\prime} 24.07 » \mathrm{~N}$ & $24^{\circ} 7^{\prime} 14.70 » \mathrm{E}$ \\
\hline $5 m$ from sulfur & $49^{\circ} 27^{\prime} 24.18 » \mathrm{~N}$ & $24^{\circ} 7^{\prime} 14.70 » \mathrm{E}$ \\
\hline $10 m$ from sulfur & $49^{\circ} 27^{\prime} 24.34 » \mathrm{~N}$ & $24^{\circ} 7^{\prime} 14.71 » \mathrm{E}$ \\
\hline $20 \mathrm{~m}$ from sulfur & $49^{\circ} 27^{\prime} 24.65 » \mathrm{~N}$ & $24^{\circ} 7^{\prime} 14.71 » \mathrm{E}$ \\
\hline
\end{tabular}

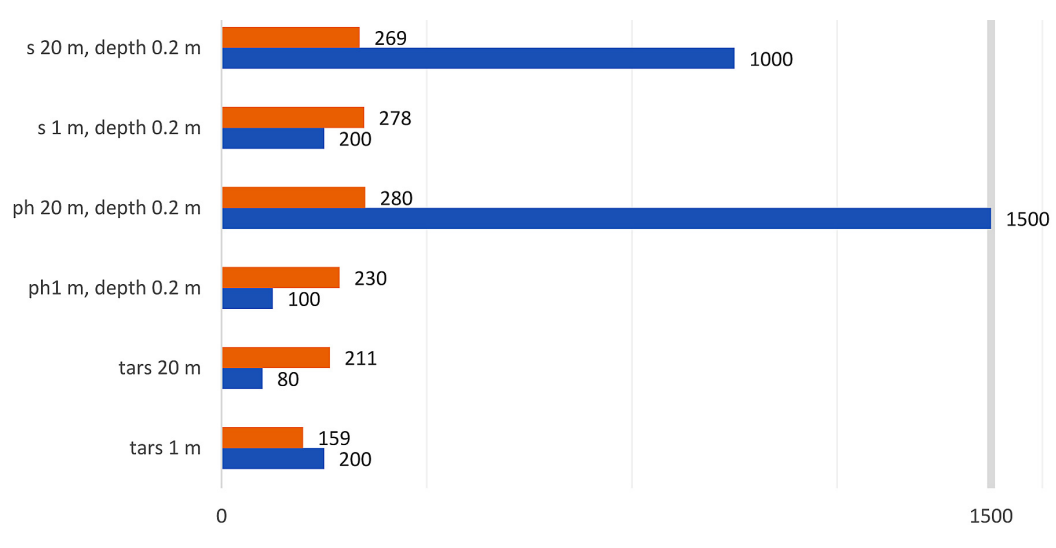

$\square 2017 \square 2016$

Fig. 3. Dynamics of Manganese content changes in soils, where $s$ is soil near the tailing's storage, $p h$ is soil near the dump of phosphogypsum, tars is a soil near the ground with oil tarts

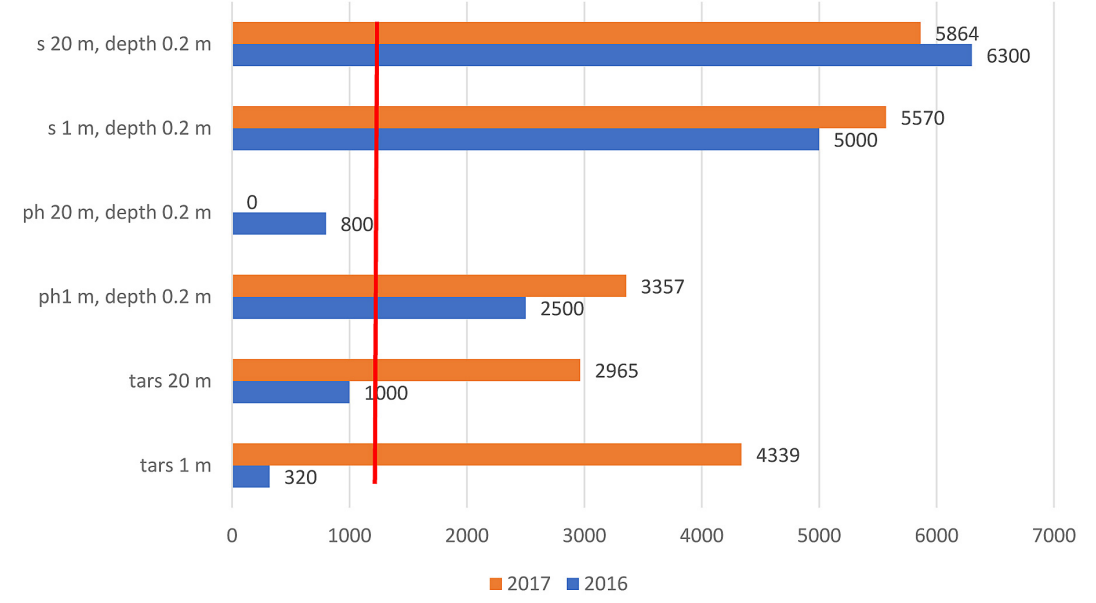

Fig. 4. Dynamics of Strontium content changes in soils, where $s$ is soil near the tailing's storage, $p h$ is soil near the dump of phosphogypsum, tars is a soil near the ground with oil tarts 


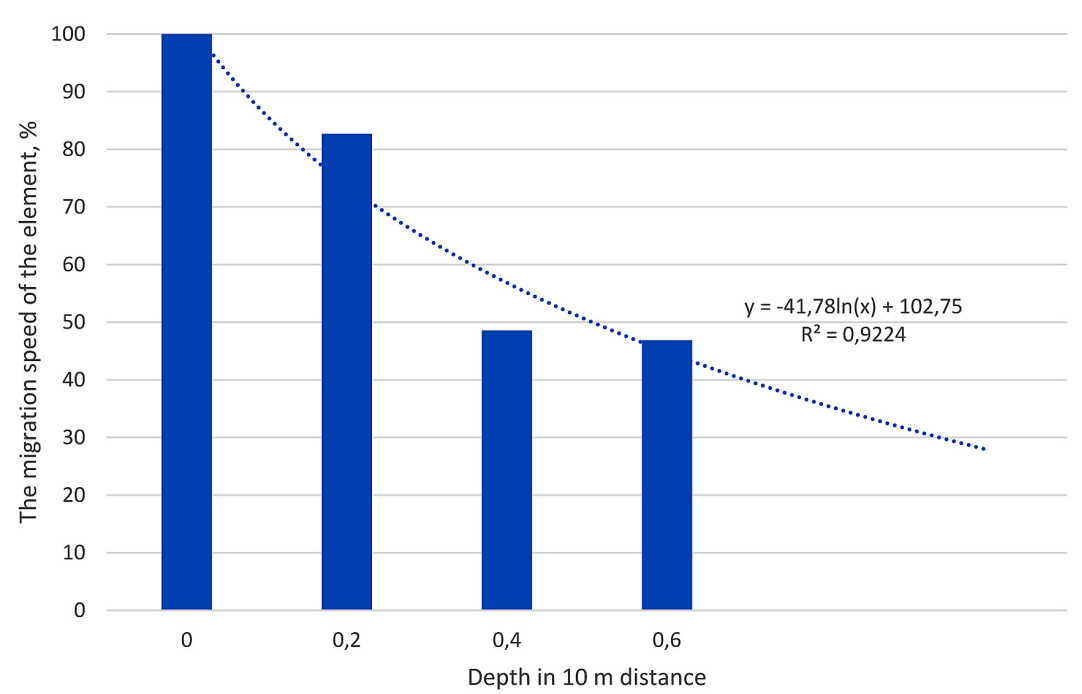

Fig. 5. Rate of Zinc migration to the depth at a distance of $10 \mathrm{~m}$ from the dump of phosphogypsum, 2017

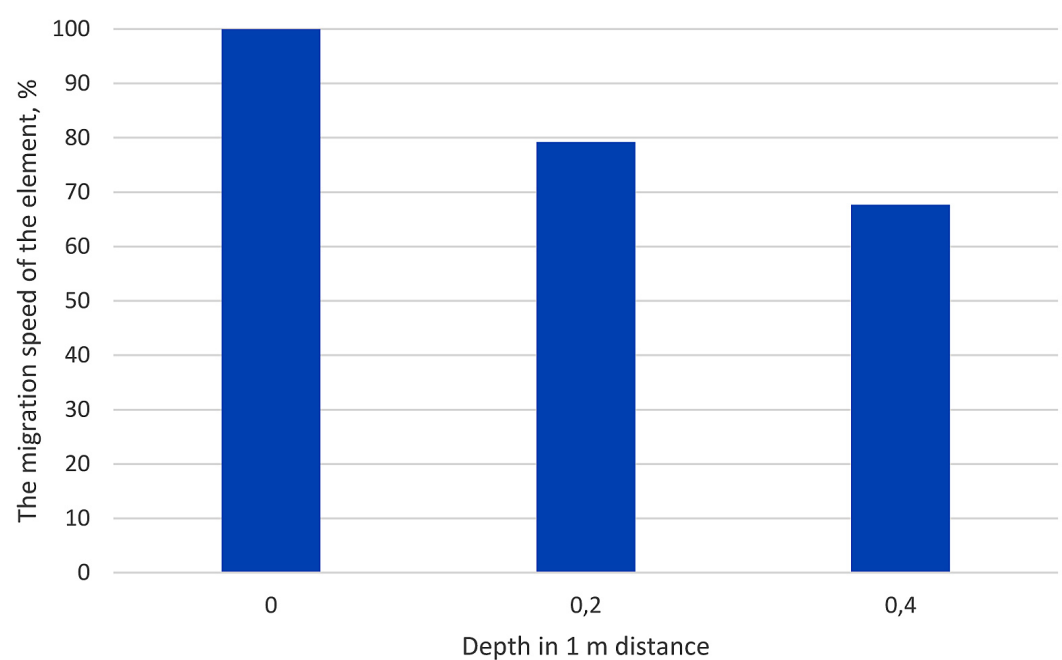

Fig. 6. Rate of Zinc migration to the depth at a distance of $1 \mathrm{~m}$ from the dump of phosphogypsum, 2017

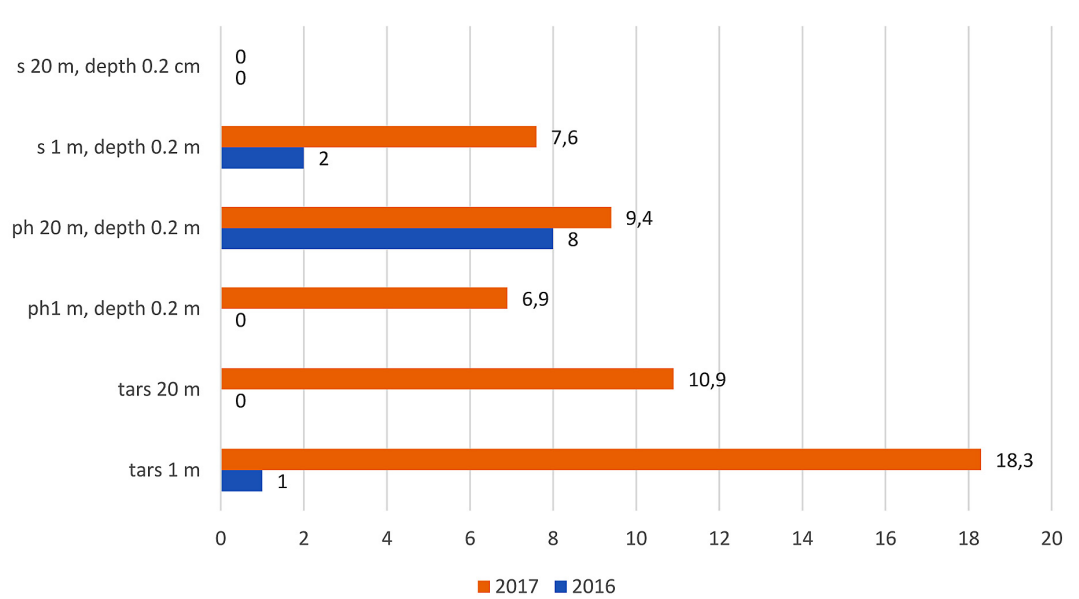

Fig. 7. Dynamics of changes of Lead content in soils, where $s$ is soil near the tailing's storage, $p h$ is soil near the dump of phosphogypsum, tars is a soil near the ground with tarts 


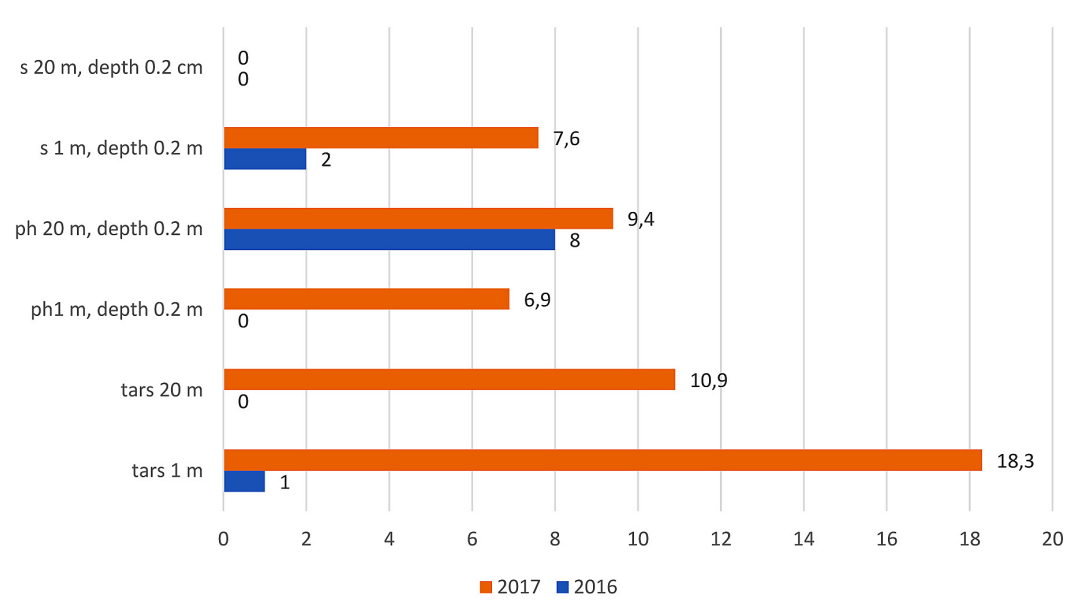

Fig. 8. Dynamics of changes of Lead content in soils, 2017, where sulfur - is soil near the tailing's storage, phosphogypsum - is soil near the dump of phosphogypsum, tars - is a soil near the ground with oil tarts

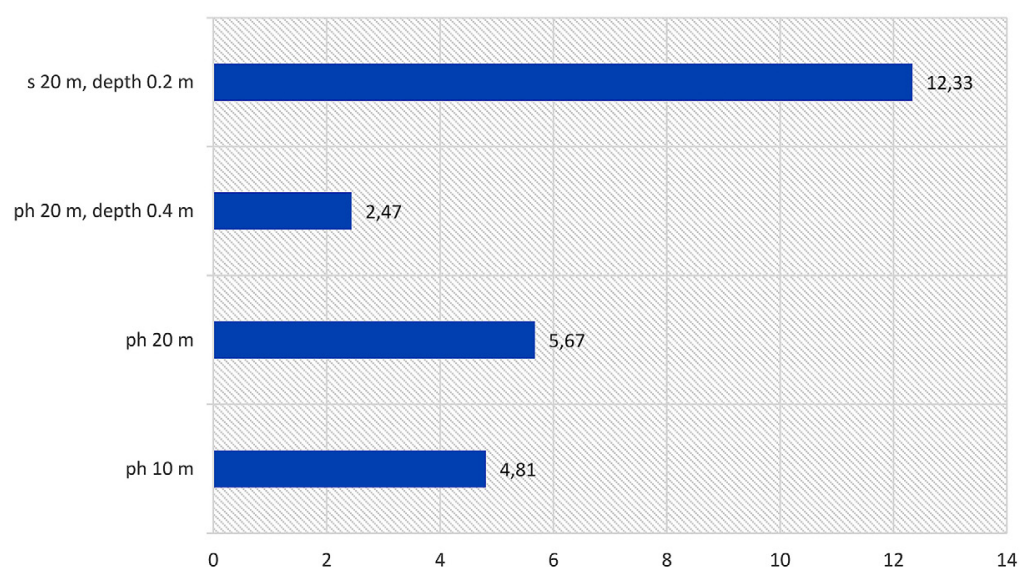

Fig. 9. Distribution of Arsenic in soils, 2017, where $s$ is soil near the tailing's storage, $p h$ is soil near the dump of phosphogypsum the tailings storage is the excess of the MPC by Arsenic by 6 times.

\section{CONCLUSION}

The parameters of soil pollution by heavy metals in the territory of Rozdil State Mining and Chemical Enterprise "Sirka" from 2016 to 2017 were analyzed in the work using the experimental method. The example of Rozdil State Mining and Chemical Enterprise "Sirka" demonstrates the main problems of the monitoring system of the territory of the mining and chemical enterprise at the stage of liquidation. The influence of the mining and chemical industry on the state of environment pollution (soil, water environment and waste management status) was assessed as well.

A significant excess of Strontium MPC (up to 6 times) was established. Over time, the contents of the element do not change, because Strontium forms a low-solubility, sedentary forms of sulphates, carbonates, phosphates. At the distance of $20 \mathrm{~m}$ from the tailings storage is the excess of the MPC by Arsenic by 6 times.
The necessity of constructing a monitoring system for the territory of Rozdil SMCE "Sirka" at the stage of liquidation was substantiated. It was established that monitoring of the territory of the mining and chemical enterprise at the stage of liquidation will allow increasing the level of environmental safety of the territory of the enterprise and the surrounding settlements.

\section{REFERENCES}

1. Bilous, L.B., Chopyk, Ya.O. 2002. Problems of monitoring of production-ecological territorial systems of the mining enterprise, Scientific Herald of Ukrainian State Forestry University, 12(1), 164-174. (in Ukrainian)

2. Kopach, P.I., Horobets, N.V., Danko, T.T., Bondarenko, L.V. 2009. The main provisions of the methodology of creating a monitoring system for the environment of mining regions, Ecology and nature management, 12, 181-187. (in Ukrainian) 
3. Gajdyn, A.M., Kovalyshyn, V.V., Saliuk, I.V. 1999. Project of reclamation of disturbed lands, the basic project decisions of restoring the ecological balance of the landscape through the phased withdrawal capacity of careers and their liquidation, Ukraine, Lviv, pp. 168. (in Ukrainian)

4. Rudko, G., Shkitsa, L. 2002. Ecological consequences of the activity of Western Ukraine mining complexes, Rocznik AGH, Wiertnictwo Nafta Gaz, Poland, 19(2), 415-418.

5. Poberezhna, L.Ya. 2015. Comprehensive assessment of the environmental risks of the territories adjacent to the Kalush-Holynskyi deposits of potassium salts, Bulletin of the Kremenchug Mykhaylo Ostrogradsky National University, 3(1), 150-156. (in Ukrainian)

6. Order of the Ministry of Emergencies of Ukraine from 06.11.2003, No. 425, On Approval of the Regulation on the Monitoring of Potentially Hazardous Objects (in Ukrainian)

7. Fetzer,J.C.2014.Mass SpectralDetection,Handbook of Spectroscopy, DOI: 10.1002/9783527654703.

8. Gauglitz, G. and Moore, D.S. (Eds.) 2014. Handbook of spectroscopy, 4 volume set, 2nd ed., Analytical and Bioanalytical Chemistry, 406(29): 7415-7416.

9. Epp, J. 2016. X-Ray Diffraction (XRD) Techniques for Materials Characterization, Materials Characterization Using Nondestructive Evaluation (NDE) Methods, DOI: 10.1016/B978-008-100040-3.00004-3.

10. Pohrebennyk, V., Mitryasova, O., Kłos-Witkowska, A., Dzhumelia, E. 2017. The role of monitoring the territory of industrial mining and chemical complexes at the stage of liquidation, 17th International Multidisciplinary Scientific GeoConference SGEM, Vienna, Austria, 17(33), 383-390.

11. Lomnytska, Ya.F., Vasylechko, V.O., Chykhrii, S.I. 2011. Composition and chemical control of environmental objects, Lviv: «Novyi Svit-2000», Ukraine, pp. 589. (in Ukrainian)
12. Bryk, M., Kołodziej, B. 2009. Reclamation problems for the area of a former borehole sulfur mine with particular reference to soil air properties, Land Degrad. Dev., 20, 509-521.

13. Pohrebennyk V., Dzhumelia, E., Korostynska, O., Mason, A., Cygnar, M. 2016. Technogenic Pollution of Soil due to Mining and Chemical Enterprises, in Proc. 16th International Multidisciplinary Scientific GeoConference SGEM, Albena, Bulgaria, ,0 June - 6 July, vol. 2, 363-370.

14. Schults, D. 1996. Recultivation of mining waste dumps in the Ruhn Area, Germany, Water, air and soil pollution, 91(1/2), 89-98.

15. Trunova, I.O. 2006. Environmental assessment of soil contamination in area of dump of phosphogypsum JSC "Sumykhimprom" by heavy metals, Herald of Sumy National University, Ukraine, 5(89), 135-138.

16. Razo, I., Carrizales, L., Castro, J., Díaz-Barriga, F., Monroy, M. 2004. Arsenic and Heavy Metal Pollution of Soil, Water and Sediments in a Semi-Arid Climate Mining Area in Mexico, Water, Air, and Soil Pollution, USA, 152(1-4), 129-152.

17. Sun, J., Geng, C.L., Zhang, Z.T., Wang, X.T. 2012. Present situation of comprehensive utilization technology of industrial solid waste, Materials Review, China, 11(2), 105-109.

18. Rybicka, E.H. 1996. Impact of mining and metallurgical industries on the environment in Poland, Applied Geochemistry, USA, 11(1-2), 3-9.

19. Pohrebennyk, V., Karpinski, M., Dzhumelia, E., Klos-Witkowska, A., Falat, P. 2018. Water bodies pollution of the mining and chemical enterprise, 18th International multidisciplinary scientific geoconference SGEM 2018 (Albena, Bulgaria, 30 June - 9 July, 2018), 18(5.2), 1035-1042.

20. Taras, U.M. 2013. Problems of rehabilitation of sulfur quarry around activity of Yavoriv State Mining and Chemical Enterprise "Sirka", Scientific Journal of UNFU of Ukraine, Ukraine, 23(2), 154-158 (in Ukrainian). 